\title{
Antihelminthic action of the Anethum graveolens essential oil on Haemonchus contortus eggs and larvae
}

\author{
L. M. Castro ${ }^{a}$ (D), N. B. Pinto (D) M. Q. Moura $^{a}$ (D), M. M. Villela (D), G. A. Capella $^{a}$ (D), \\ R. A. Freitag ${ }^{b}$ (D) and M. E. A. Berne $e^{a}$ (D)
}

a'Laboratório de Parasitologia, Departamento de Microbiologia e Parasitologia, Instituto de Biologia, Universidade Federal de Pelotas - UFPel, Campus Universitário, s/n, Capão do Leão, Prédio 25, Sala 12, CEP 96010-900, Pelotas, RS, Brasil

'Laboratório de Química Orgânica, Departamento de Química, Universidade Federal de Pelotas - UFPel, CEP 96010-900, Pelotas, RS, Brasil

*e-mail: nbernevet@gmail.com

Received: July 10, 2019 - Accepted: September 26, 2019 - Distributed: February 28, 2021

\begin{abstract}
Gastrointestinal nematodes are responsible for great economic losses in sheep raising, and their control has long been carried out almost exclusively by the administration of anthelmintics, which have led to serious resistance problems. In the search for alternative control measures, phytotherapic research is highlighted. The aim of this study was to evaluate the action of Anethum graveolens (dill) essential oil on different stages of Haemonchus contortus life cycle, as well its cytotoxicity MDBK (Madin-Darby bovine kidney) cells. H. contortus larvae and eggs were obtained from infected sheep feces, and essential oil extracted from plant seeds through the Clevenger apparatus. 9.4, 4.7, 2.35, 1.17. 0.58 and $0.29 \mathrm{mg} / \mathrm{mL}$ concentrations were evaluated. The Egg Hatch Inhibition (HI), Larval Development Inhibition (LDI) and Larval Migration Inhibition (LMI) techniques were used. Thybendazole $0.025 \mathrm{mg} / \mathrm{mL}$ in HI and Levamisole $0.02 \mathrm{mg} / \mathrm{mL}$ in the LDI and LMI tests were used as positive controls, while distilled water and a Tween 80 solution were used as positive negative controls. The inhibition results obtained for the highest oil concentration were: HI 100\%, LDI 98.58\% and LMI $63.7 \%$, differing $(p<0.05)$ from negative controls. Main A. graveolens oil components present in $95.93 \%$ of the total oil were Dihydrocarvone (39.1\%), Carvone (22.24\%), D-Limonene (16.84\%), Apiol (10.49\%) and Trans-dihydrocarvone (7.26\%). Minimum A. graveolens essential oil concentrations required to inhibit 50\% (IC50) of egg hatching, larval development and larval migration were $0.006 \mathrm{mg} / \mathrm{mL}, 2.536 \mathrm{mg} / \mathrm{mL}$ and $3.963 \mathrm{mg} / \mathrm{mL}$, respectively. Cell viability in MDBK (Madin-Darby bovine kidney) cells, when incubated with A. graveolens essential oil, was $86 \%$ for the highest $(9.4 \mathrm{mg} / \mathrm{mL})$ and $99 \%$ for the lowest concentration $(0.29 \mathrm{mg} / \mathrm{mL})$. A. graveolens essential oil, according to the results obtained in this study, is a promising alternative in sheep gastrointestinal nematode control.
\end{abstract}

Keywords: essential oil, dill, nematodes, sheep.

\section{Ação anti-helmítica do óleo essencial de Anethum graveolens sobre ovos e larvas de Haemonchus contortus}

\section{Resumo}

Os nematoides gastrintestinais são responsáveis por grandes perdas econômicas na ovinocultura, e seu controle tem sido realizado quase exclusivamente pela administração de anti-helmínticos, que levaram a sérios problemas de resistência. $\mathrm{Na}$ busca de medidas alternativas de controle, destaca-se a pesquisa fitoterápica. O objetivo deste trabalho foi avaliar a ação do óleo essencial de Anethum graveolens (endro) em diferentes estágios de Haemonchus contortus, bem como testar a viabilidade celular para o óleo. Larvas e ovos de $H$. contortus foram obtidos de fezes de ovinos infectados e óleo essencial extraído de sementes de plantas através do aparelho de Clevenger. As concentrações avaliadas foram $9,4,4,7,2,35,1,17,0,58$ e 0,29 mg/mL. Verificou-se a Inibição de eclosão dos ovos (IE), Inibição de Desenvolvimento Larval (IDL) e Inibição de Migração Larval (IML). Tiabendazol 0,025 mg/mL em IE e Levamisole $0.02 \mathrm{mg} / \mathrm{mL}$ nos testes IDL e IML foram usados como controles positivos, enquanto água destilada e uma solução Tween 80 foram usados como controles negativos. Os resultados de inibição obtidos para a maior concentração de óleo foram: IE 100\%, IDL 98,58\% e IML 63,7\%, diferindo $(p<0,05)$ dos controles negativos. Os principais componentes presentes em 95,93\% do óleo total de $A$. graveolens foram Di-hidrocarvona (39,1\%), Carvona (22,24\%), D-Limoneno (16,84\%), Apiol (10,49\%) e Trans-di-hidrocarvona (7,26\%). As concentrações mínimas de óleo essencial de A. graveolens necessárias para inibir 50\% (IC50) de eclosão dos ovos, desenvolvimento larval e migração larval foram de $0,006 \mathrm{mg} / \mathrm{mL}$, $2,536 \mathrm{mg} / \mathrm{mL}$ e $3,963 \mathrm{mg} / \mathrm{mL}$, respectivamente. A viabilidade celular nas células MDBK (rim bovino Madin-Darby), 
quando incubadas com o óleo essencial de $A$. graveolens, foi de $86 \%$ para a maior $(9,4 \mathrm{mg} / \mathrm{mL})$ e $99 \%$ para a menor concentração $(0,29 \mathrm{mg} / \mathrm{mL})$. O óleo essencial de $A$. graveolens mostrou ser uma alternativa promissora no controle de nematoides gastrintestinais de ovinos.

Palavras-chave: óleo essencial, endro, nematódeos, ovelha.

\section{Introduction}

Sheep gastrointestinal nematodes are thought to be a major health problem faced by these animals around the world, and infections caused by these parasites are responsible for great losses in sheep raising (Acharya et al., 2014).

The control of these parasites has been carried out for decades, and has been mostly done by the administration of commercial anthelmintics; however, major ruminant nematodes are resistant to many of the available active principles, which is an obstacle to sheep farming (Cezar et al., 2010). Thus, different control approaches are necessary, either through parasite-resistant animals, the use of probiotics (Pinto et al., 2017) or the use of herbal medicine (Carvalho et al., 2012; Coêlho et al., 2017).

Studies making use of different plants have shown the anthelmintic potential on small ruminant nematodes (Acharya et al., 2014; Katiki et al., 2017). Anethum graveolens (dill), of the Apiaceae family, is an aromatic plant originally from Mediterranean countries which has been widely used as seasoning in the preparation of different foods (Słupski et al., 2005). It has also been used in traditional herbal medicine as a diuretic and gastrointestinal disorder treatment (Hosseinzadeh et al., 2002). Studies have shown that $A$. graveolens acts against bacteria (Kaur and Arora, 2009), fungi (Kumarasingha et al., 2016; Vieira et al., 2019), protozoa (Sahib et al., 2014) and insects (Khani and Basavand, 2013), although for the latter group their pollen grains may be used to feed certain orders (D'Ávila et al., 2016).

The present study aimed to evaluate the action of A. graveolens essential oil against against Haemonchus contortus eggs and larvae. In addition, in vitro cytotoxicity was also verified.

\section{Material and Methods}

\subsection{Essential oil collection and chemical analysis}

The plant used in the experiment, A. graveolens (dill), was purchased from a commercial distributor, having quality and origin certification (ET - 006/Anethun graveolens - Semente, LuarSulAlimentos $\left.{ }^{\circledR}\right)$. To obtain the essential oil, seeds were subjected to steam extraction in a Clevenger apparatus for $4 \mathrm{~h}$. Afterwards, the oil obtained was dried with sodium sulfate, sodium p.a. anhydrous, stored in an amber flask and maintained at $-18^{\circ} \mathrm{C}$ until use. For chemical analysis, the $A$. graveolens essential oil was subjected to gas chromatographic analysis together with mass spectrometry model GC/MS-QP 2010SE (Shimadzu, Japan). The sample was submitted an initial temperature of $40^{\circ} \mathrm{C}$, with a heating temperature of $5^{\circ} \mathrm{C} / \mathrm{min}$ to $280^{\circ} \mathrm{C}$, maximum temperature of $58^{\circ} \mathrm{C}$, the injector temperature being $58^{\circ} \mathrm{C}$ and the interface $200{ }^{\circ} \mathrm{C}$.

\subsection{Cytotoxicity test}

The cytotoxic effect of $A$. graveolens was determined by the MTT (Thiazolyl Blue Tetrazolium Bromide) assay, as described by Mosmann (1983), by using Madin-Darby bovine kidney (MDBK) cells. This test was performed using the A. graveolens essential oil at the concentrations $9.4 \mathrm{mg} / \mathrm{mL}$; $4.7 \mathrm{mg} / \mathrm{mL} ; 2.35 \mathrm{mg} / \mathrm{mL}, 1.17 \mathrm{mg} / \mathrm{mL} ; 0.58 \mathrm{mg} / \mathrm{mL}$ and $0.29 \mathrm{mg} / \mathrm{mL}$, with the control using cell culture media MEM (Minimum Essential Media). All assays were in duplicated and cytotoxicity was evaluated by absorbance on the $540 \mathrm{~nm}$ mass spectrophotometer.

\subsection{Gastrointestinal nematode eggs}

In order to obtain the eggs, six experimentally infected sheep with Haemonchus contortus showing EPG above 2000 eggs per gram of feces (Gordon and Whitlock, 1939) were used and kept indoors at the Federal University of Pelotas. Feces collected directly from the animals' rectal ampulla were processed according to Hubert and Kerboeuf's (1992) technique to separate eggs from fecal matter impurities. Briefly, the samples passed through four mesh sieves the size $1 \mathrm{~mm}, 105 \mu \mathrm{m}, 55 \mu \mathrm{m}$ and $25 \mu \mathrm{m}$. The first three were intended to retain the largest particles, and the last for egg retention.

This study was approved by the Ethics Committee on Animal Experimentation of the Federal University of Pelotas - UFPel, under number 3897.

\subsection{Gastrointestinal nematode larvae}

To perform the tests, it was necessary to obtain $1^{\text {st }}(\mathrm{L} 1)$ and $3^{\text {rd }}$ stage (L3) larvae. L1 were retrieved by incubating feces containing $H$. contortus eggs in an incubator at $28^{\circ} \mathrm{C}$ and $80 \%$ relative humidity. After $24 \mathrm{~h}$ incubation, the flasks containing the feces were covered with water and inverted, and L1 were collected after 4 hours, while L3 was obtained by using Roberts and O'Sullivan's (1950) technique; after being retrieved, the parasites were identified and separated.

\subsection{Egg hatch inhibition test}

The hatch test was based on the methodology as described by Coles et al. (1992), for which 24-well microculture plates were used. In each well, $150 \mathrm{H}$. contortus eggs were added together with $A$. graveolens, essential oil at six different concentrations $(9.4,4.7,2.35,1.17,0.58$ and $0.29 \mathrm{mg} / \mathrm{mL})$; distilled water was used as negative control, and Tiabendazole $0.025 \mathrm{mg} / \mathrm{mL}$ and Tween 80 ( $1 \%$ of the final solution) were used as positive control; the latter was used to emulsify the oils in their dilutions. After 48 hours, Lugol was added for the purpose of interrupting hatching, and eggs and larvae were counted using an inverted microscope. Each treatment 
was performed in four replicates. Hatchability inhibition means for each treatment were determined according to the equation as described by Camurça-Vasconcelos et al. (2007), namely \% Hatchability Inhibition = number of larvae / (number of larvae + number of eggs) X 100.

\subsection{Larval development inhibition test}

The larval development test was performed according to the method as described by Roberts and O'Sullivan (1950), adapted. For each treatment, a $1 \mathrm{~mL}$ aliquot (containing $2501^{\text {st }}$ stage larvae) was used, which was then incubated for 6 days with $2 \mathrm{~g}$ feces from a gastrointestinal nematode-free animal, together with $1 \mathrm{~mL}$ A. graveolens essential oils at $9.4,4.7,2.35,1.17,0.58$ and $0.29 \mathrm{mg} / \mathrm{mL}$ concentrations.

The negative control consisted of the culture treated with distilled water and with Tween 80 ( $1 \%$ of final solution), and the positive control by $0.02 \mathrm{mg} / \mathrm{mL}$ Levamisole, all with four replicates. Third stage larva was performed after culture larva collection, which was then added with Lugol and visualized under an inverted microscope. The inhibition percentage was given by the following formula: \% larval development inhibition $=$ (number of larvae in the control - number of larvae in treatment)/number of larvae in control x 100 .

\subsection{Larval migration inhibition test}

To perform the technique, third stage larvae were placed in six-well polyethylene plates and allowed in a $25 \mu \mathrm{m}$ mesh sieve to migrate for an hour so as viable larvae could be selected. After this initial selection, L3 larvae were added with a $0.6 \%$ sodium hypochlorite solution for approximately $20 \mathrm{~min}$. so that the larvae exsheathment could occur. Following, three washes with distilled water, centrifugation at $203 \mathrm{~g}$ for 2 min were performed and the final volume suitability of 150 larvae in $100 \mu \mathrm{L}$ water was obtained (Demeler et al., 2010). These were incubated with $900 \mu \mathrm{L}$ A. graveolens essential oil at 9.4, 4.7, 2.35, 1.17, 0.58 and $0.29 \mathrm{mg} / \mathrm{mL}$ and kept in an incubator at $28{ }^{\circ} \mathrm{C}$ for 24 hours in two replicates.

Distilled water and Tween 80 ( $1 \%$ of final solution) were used as negative control, whereas positive control was performed with $0.02 \mathrm{mg} / \mathrm{mL}$ Levamisole. After the incubation period, the contents of each well containing L3 were transferred to $25 \mu \mathrm{m}$ mesh sieves and re-incubated at $28{ }^{\circ} \mathrm{C}$ for 24 hours. The sieves were then removed and washed with distilled water to wash away retained contents, followed by counting larvae that migrated and those retained by the sieves under an inverted microscope. The larval migration inhibition means for each treatment were calculated using the equation: \% larval migration inhibition $=$ Number of larvae that did not migrate/(Number of larvae that did not migrate + Number of larvae that migrated) X 100.

\subsection{Statistical analysis}

Analysis of Variance (ANOVA), followed by multiple comparison Tukey's test, was applied at a 5\% probability level using the GraphPad Prism version 7.0 software. The 50\% inhibitory concentration (IC50) capable of inhibiting 50\% of egg hatch, larval development and larval migration was determined from the concentration-response curve, with a 95\% confidence interval by means of the GraphPad Prism software version 5.0 for Windows.

\section{Results}

A. graveolens essential oil yield, according to the methodology used in the extraction, was $1.3 \mathrm{~mL} / 100 \mathrm{~g}$ seed. Gas chromatography associated with mass spectrometry showed 5 major $A$. graveolens oil components which were present in $95.93 \%$ of the total oil: $39.1 \%$ Dihydrocarvone, 22.24\% Carvone, 16.84\% D -Limonene, 10.49\% Apiol and $7.26 \%$ Trans-dihydrocarvone.

Table 1 shows the results of $A$. graveolens essential oil activity at different $H$. contortus development stages (eggs, first stage larvae - L1 and infective larvae - L3). In the egg hatch inhibition test, it could be observed that only the lowest concentration $(0.29 \mathrm{mg} / \mathrm{mL})$ was statistically different from the anthelmintic control. In the larval development inhibition test, only the two highest concentrations ( 9.4 and $4.7 \mathrm{mg} / \mathrm{mL}$ ) showed no statistical differences from the control with anthelmintic, whereas in the larval migration inhibition test only the highest

Table 1. Percentage of activity of the essential oil of Anethum graveolens in the different stages of development of Haemonchus contortus.

\begin{tabular}{cccc}
\hline Treatment & Egg hatch inhibition (\%) & $\begin{array}{c}\text { Larval development } \\
\text { inhibition (\%) }\end{array}$ & $\begin{array}{c}\text { Larval migration } \\
\text { inhibition (\%) }\end{array}$ \\
\hline Control & $3.4^{\mathrm{d}}$ & $0^{\mathrm{c}}$ & $6.3^{\mathrm{e}}$ \\
Tween 80 & $7.05^{\mathrm{c}}$ & $2.12^{\mathrm{c}}$ & $10.8^{\mathrm{e}}$ \\
ATH & $100^{\mathrm{a}}$ & $99.50^{\mathrm{a}}$ & $82.05^{\mathrm{a}}$ \\
$9.4 \mathrm{mg} / \mathrm{mL}$ & $100^{\mathrm{ab}}$ & $98.58^{\mathrm{a}}$ & $63.7^{\mathrm{ab}}$ \\
$4.7 \mathrm{mg} / \mathrm{mL}$ & $99.30^{\mathrm{ab}}$ & $83.16^{\mathrm{ab}}$ & $46.75^{\mathrm{bc}}$ \\
$2.35 \mathrm{mg} / \mathrm{mL}$ & $99.35^{\mathrm{ab}}$ & $30.88^{\mathrm{bc}}$ & $47.05^{\mathrm{bc}}$ \\
$1.17 \mathrm{mg} / \mathrm{mL}$ & $98.90^{\mathrm{ab}}$ & $25.40^{\mathrm{c}}$ & $37.1^{\mathrm{cd}}$ \\
$0.58 \mathrm{mg} / \mathrm{mL}$ & $98.57^{\mathrm{ab}}$ & $19.11^{\mathrm{c}}$ & $18.75^{\mathrm{de}}$ \\
$0.29 \mathrm{mg} / \mathrm{mL}$ & $96.40^{\mathrm{b}}$ & $0.49^{\mathrm{c}}$ & $13.00^{\mathrm{de}}$ \\
\hline
\end{tabular}

Different letters in the same column indicate significant differences $(\mathrm{p}<0.05)$. ATH $=$ antihelmintic. 
concentration $(9.4 \mathrm{mg} / \mathrm{mL})$ was statistically similar to anthelmintic control results.

In the evaluation of $A$. graveolens essential oil cytotoxicity in MDBK (Madin-Darby Bovine Kidney) cells, cell viability (\%) at the different concentrations tested was: $9.4 \mathrm{mg} / \mathrm{mL}$ (86\%); $4.7 \mathrm{mg} / \mathrm{mL}$ (89\%); $2.35 \mathrm{mg} / \mathrm{mL}$ (96\%), $1.17 \mathrm{mg} / \mathrm{mL}(96 \%) ; 0.58 \mathrm{mg} / \mathrm{mL}(96 \%)$ and $0.29 \mathrm{mg} / \mathrm{mL}(99 \%)$.

The minimum A. graveolens essential oil concentration necessary to inhibit 50\% egg hatchability (IC50) was $0.006 \mathrm{mg} / \mathrm{mL}$, while the IC50 for larval development inhibition and larval migration were $2.536 \mathrm{mg} / \mathrm{mL}$ and $3.963 \mathrm{mg} / \mathrm{mL}$, respectively.

\section{Discussion}

The use of plants has proved to be a promising alternative in the control of small ruminant nematodes. In addition to showing anthelmintic activity, it is a sustainable practice, since it reduces the risk of chemical residues in animal products and in the environment (Chagas et al., 2008). In this study, the results of $A$. graveolens essential oil action against $H$. contortus eggs were promising, with $100 \%$ hatch inhibition (HI) at the highest concentration $(9.4 \mathrm{mg} / \mathrm{mL})$, not differing much $(\mathrm{p}<0.05)$ from the $0.58 \mathrm{mg} / \mathrm{mL}$ concentration $(98.57 \%)$. These results were similar to those found by an Ocimum basilicum essential oil study, which found a $100 \%$ H. contortus $\mathrm{HI}$ at a $0.5 \mathrm{mg} / \mathrm{mL}$ concentration (Castro et al., 2017), as well as for Croton zehntneri and Lippia sidoides essential oils, which inhibited $98 \%$ of $H$. contortus egg hatching at $1.25 \mathrm{mg} / \mathrm{mL}$ (Camurça-Vasconcelos et al., 2007), and $5.3 \mathrm{mg} / \mathrm{mL}$ Eucalipypus citriodora, which showed a 98.8\% hatch inhibition (Macedo et al., 2009). Although studies with essential oils from different plants have shown their efficacy in $H$. contortus egg HI, this has only been reached at much higher concentrations than those obtained by the present study. Macedo et al. (2009), using Eucalipypus globulus essential oil, obtained 99.3\% HI at the $21.75 \mathrm{mg} / \mathrm{mL}$, and Pessoa et al. (2002), upon evaluating Ocimum gratissimum, found a $100 \% \mathrm{HI}$ at $50 \mathrm{mg} / \mathrm{mL}$ concentration. Although some plants may present common components, these differ in concentration levels; also, the anthelmintic action can be potentiated by a synergistic effect between different components (Katiki et al., 2017; Ma et al., 2015).

Larval development inhibition (LDI) showed 98.58\% efficacy at its highest concentration $(9.4 \mathrm{mg} / \mathrm{mL})$ - similar to that of anthelmintic treatment - inactivating the development of the infectious phase (L3). The results obtained in the present study were similar to those obtained by Macedo et al. (2009) with Eucalyptus globulus essential oil, with $98.7 \%$ LDI at a $21.75 \mathrm{mg} / \mathrm{mL}$ concentration, which was also observed by Camurça-Vasconcelos et al. (2007) with Lippia sidoides essential oil, who obtained $94.5 \% \mathrm{LDI}$ at a $20 \mathrm{mg} / \mathrm{mL}$ concentration. These results, however, were obtained using concentrations much higher than those evaluated in this study, which may indicate a higher $A$. graveolens essential oil anthelmintic potential.
In the larval migration inhibition test (LMI), the 9.4 $\mathrm{mg} / \mathrm{mL}$ concentration obtained $63.7 \%$ efficacy; a similar study carried out by Yoshihara et al. (2014), who tested condensed tannins extracted from Acacia mearnsii, found that the $12.5 \mathrm{mg} / \mathrm{mL}$ concentration showed $56.3 \%$ inhibition, and only reaching $97.1 \%$ at the highest concentration used - $100 \mathrm{mg} / \mathrm{mL}$, thus demonstrating that better results can be obtained with a concentration increase. When analyzing the results of $A$. graveolens essential oil action in the different $H$. contortus development phases, L3 was found to be the most resistant, which can be attributed to the presence of the double cuticle at this larval stage as well as to the lower metabolic activity that occurs at this stage, a fact which was also mentioned by Amarante et al. (2014).

Essential oils comprise a complex combination of volatile substances extracted from plants containing several tens or even hundreds of substances with diverse chemical composition. However, most often one or more substances prevail, determining the major components that characterize the plant species under analysis and its properties (Bakkali et al., 2008). The major components identified in A. graveolens oil in this study were also present in other investigations (Singh et al., 2005; Orhan et al., 2013; Sintim et al., 2015), though their compound concentration differs, showing that these are dependent on several factors such as the area where the plant was raised, type of crop, and the extraction technique it was submitted (Chahal et al., 2017).

Another important factor that has been detected is the synergistic action of $A$. graveolens essential oil components, as observed by Ma et al. (2015) who, upon evaluating the activity of this oil against the fungus Sclerotinia sclerotiorum, found that two of its main components, carvone and limonene, synergistically inhibited the growth of this fungus. Limonene is found in oils from different plants with anthelmintic activity, such as Lippia sidoides, Cymbopogon martinii, Mentha piperita and Eucalyptus staigeriana (Katiki et al., 2011; Carvalho et al., 2012; Ribeiro et al., 2013). In agreement with this finding, it has been found that limonene accounts for $96 \%$ of Citrus sinensis essential oil composition, causing $100 \%$ in vitro inhibition of $H$. contortus eggs and larvae in most concentrations tested (Gaínza et al., 2015). It is possible that these two compounds present in A. graveolens essential oil may also be the major components of the anthelmintic action on $H$. contortus observed in the present study.

For a product to be considered a good infection control agent, causing no harm to the host is as important as the deleterious effect of phytotherapic on the parasite. Although the toxic effect of some plants that have already been described, other studies have already shown an opposite effect, a protection against the toxicity of other chemicals (Boriollo et al., 2018). In a study with $A$. graveolens leaf extract containing silver nanoparticles, Kalangi et al. (2016) performed the same cell viability assay and observed at the highest concentration of $100 \mathrm{mg}$ a viability of $82 \%$. Even using concentrations much lower than these, the present 
study obtained a similar, satisfactory cell viability (86\%) at the highest concentration.

As to $A$. graveolens essential oil IC50 evaluation, this was higher for larval migration $(3.963 \mathrm{mg} / \mathrm{mL})$; this result was inferior to the parameters established by Adamu et al. (2013), in which a plant extract showing an EC50 below $6 \mathrm{mg} / \mathrm{mL}$ presented a great anthelmintic potential, corroborating the present finding.

\section{Conclusion}

The study of plants through their essential oils with action on gastrointestinal nematodes has the potential to obtain molecules with anthelmintic activity and, in this context, and even aware of the importance of in vivo testing, the results presented here show that the A. graveolens essential oil is a promising source of biomolecules with proven anthelmintic activity from the techniques employed.

\section{References}

ACHARYA, J., HILDRETH, M.B. and REESE, R.N., 2014. In vitro screening of forty medicinal plant extracts from the United States Northern Great Plains for anthelmintic activity against Haemonchus contortus. Veterinary Parasitology, vol. 201, no. 1-2, pp. 75-81. http://dx.doi.org/10.1016/j.vetpar.2014.01.008. PMid:24548703.

ADAMU, M., NAIDOO, O.V. and ELOFF, J.N., 2013. Efficacy and toxicity of thirteen plant leaf acetone extracts used in ethno veterinary medicine in South Africa on egg hatching and larval development of Haemonchus contortus. BMC Veterinary Research, vol. 9, no. 1, pp. 38. http://dx.doi.org/10.1186/1746-6148-9-38. PMid:23442744.

AMARANTE, A.F.T.D., RAGOZO, A. and SILVA, B.F.D., 2014. Os parasitas de ovinos. São Paulo; Editora Unesp Digital. http:// dx.doi.org/10.7476/9788568334423.

BAKKALI, F., AVERBECK, S., AVERBECK, D. and IDAOMAR, M., 2008. Biological effects of essential oils: a review. Food and Chemical Toxicology, vol. 46, no. 2, pp. 446-475. http://dx.doi. org/10.1016/j.fct.2007.09.106. PMid:17996351.

BORIOLLO, M.F.G., SILVA, T.A., RODRIGUES-NETTO, M.F., SILVA, J.J., MARQUES, M.B., DIAS, C.T.S., HÖFLING, J.F., RESCK, M.C.C. and OLIVEIRA, N.M.S., 2018. Reduction of doxorubicin-induced genotoxicity by Handroanthus impetiginosus in mouse bone marrow revealed by micronucleus assay. Brazilian Journal of Biology $=$ Revista Brasileira de Biologia, vol. 78, no. 1, pp. 1-12. http://dx.doi.org/10.1590/1519-6984.18515. PMid:28699970.

CAMURÇA-VASCONCELOS, A.L.F., BEVILAQUA, C.M.L., MORAIS, S.M., MACIEL, M.V., COSTA, C.T., MACEDO, I.T., OLIVEIRA, L.M., BRAGA, R.R., SILVA, R.A. and VIEIRA, L.S., 2007. Anthelmintic activity of Croton zehntneri and Lippia sidoides essential oils. Veterinary Parasitology, vol. 148, no. 3-4, pp. 288-294. http://dx.doi.org/10.1016/j.vetpar.2007.06.012. PMid:17629623.

CARVAlHO, C.O., CHAGAS, A.C.S., COTINGUIBA, F., FURLAN, M., BRITO, L.G., CHAVES, F.C.M., STEPHAN, M.P., BIZZO, H.R. and AMARANTE, A.F.T., 2012. The anthelmintic effect of plant extracts on Haemonchus contortus and Strongyloides venezuelensis. Veterinary Parasitology, vol. 183, no. 3-4, pp. 260-268. http://dx.doi.org/10.1016/j.vetpar.2011.07.051. PMid:21872995.

CASTRO, L.M., PINTO, N.B., DIAS DE CASTRO, L.L., MOURA, M.Q., MOTA, T.O., MADRID, I.M., FREITAG, R.A. and BERNE, M.E.A., 2017. Atividade ovicida do óleo essencial e do extrato hidroalcoólico de Ocimum basilicum sobre nematódeos gastrintestinais de ovinos. Science and Animal Health, vol. 5, no. 2, pp. 138-150. http://dx.doi.org/10.15210/sah.v5i2.10726.

CEZAR, A.S., TOSCAN, G., CAMILLO, G., SANGIONI, L.A., RIBAS, H.O. and VOGEL, F.S.F., 2010. Multiple resistance of gastrointestinal nematodes to nine different drugs in a sheep flock in southern Brazil. Veterinary Parasitology, vol. 173, no. 1-2, pp. 157-160. http://dx.doi.org/10.1016/j.vetpar.2010.06.013. PMid:20619543.

CHAGAS, A.C.S., VIEIRA, L.S., FREITAS, A.R., ARAÚJO, M.R.A., ARAÚJO-FILHO, J.A., ARAGUAO, W.R. and NAVARRO, A.M.C., 2008. Anthelmintic efficacy of neem (Azadirachta indica A. Juss) and the homeopathic product Fator Vermes ${ }^{\circledR}$ in Morada Nova sheep. Veterinary Parasitology, vol. 151, no. 1, pp. 68-73. http://dx.doi.org/10.1016/j.vetpar.2007.10.003. PMid:18022188.

CHAHAL, K.K., MONIKA, KUMAR, A., BHARDWAJ, U. and KAUR, R., 2017. Chemistry and biological activities of Anethum graveolens L. (dill) essential oil: a review. Journal of Pharmacognosy and Phytochemistry, vol. 6, no. 2, pp. 295-306.

COÊLHO, M.D.G., XAVIER, T.B., COSTA, J.F.D., MACIEL, L.T.R., BOZO, L.S.O., COÊLHO, F.A.D.S. and AKISUE, G., 2017. Evaluation of plant extracts to control haemonchosis in naturally infected sheep. Revista Ambiente \& Água, vol. 12, no. 2, pp. 331-339. http://dx.doi.org/10.4136/ambi-agua.2020.

COLES, G.C., BAUER, C., BORGSTEEDE, F.H.M., GEERTS, S., KLEI, T.R., TAYLOR, M.A. and WALLER, P.J., 1992. World Association for the advancement of Veterinary Parasitology (W.A.A.V.P.) methods for detection of anthelmintic resistance in nematodes of veterinary importance. Veterinary Parasitology, vol. 44, no. $1-2$, pp. 35-44. http://dx.doi.org/10.1016/03044017(92)90141-U. PMid:1441190.

D’Ávila, V.A., AGUIAR-MENEZES, E.L., GONÇALVESESTEVES, V., MENDONÇA, C.B., PEREIRA, R.N. and SANTOS, T.M., 2016. Morphological characterization of pollens from three Apiaceae species and their ingestion by twelve-spotted lady beetle (Coleoptera: coccinellidae). Brazilian Journal of Biology $=$ Revista Brasileira de Biologia, vol. 76, no. 3, pp. 796-803. http://dx.doi. org/10.1590/1519-6984.07615. PMid:27097091.

DEMELER, J., KÜTTLER, U., EL-ABDELLATI, A., STAFFORD, K., RYDZIK, A., VARADY, M., KENYON, F., COLES, G., HÖGLUND, J., JACKSON, F., VERCRUYSSE, J. and VON SAMSON-HIMMELSTJERNA, G., 2010. Standardization of the larval migration inhibition test for the detection of resistance to ivermectin in gastrointestinal nematodes of ruminants. Veterinary Parasitology, vol. 174, no. 1-2, pp. 58-64. http://dx.doi.org/10.1016/j. vetpar.2010.08.020. PMid:20850930.

GAÍNZA, Y.A., DOMINGUES, L.F., PEREZ, O.P., RABELO, M.D., LÓPEZ, E.R. and CHAGAS, A.C.S., 2015. Anthelmintic activity in vitro of Citrus sinensis and Melaleuca quinquenervia essential oil from Cuba on Haemonchus contortus. Industrial Crops and Products, vol. 76, pp. 647-652. http://dx.doi.org/10.1016/j. indcrop.2015.07.056.

GORDON, H.M. and WHITLOCK, H.V.A., 1939. New technique for counting nematode eggs in sheep faeces. Journal of the Council for Scientific and Industrial Research, vol. 12, pp. 50-52. 
HOSSEINZADEH, H., KARIMI, G. and AMERI, M., 2002. Effects of Anethum graveolens L. seed extracts on experimental gastric irritation models in mice. BMC Pharmacology, vol. 2, no. 1, pp. 21. http://dx.doi.org/10.1186/1471-2210-2-21. PMid:12493079.

HUBERT, J. and KERBOEUF, D.A., 1992. Microlarval development assay for the detection of anthelmintic resistance in sheep nematodes. Veterinary Research, vol. 130, no. 20, pp. 442-446. http://dx.doi.org/10.1136/vr.130.20.442. PMid:1621342.

KALANGI, S.K., DAYAKAR, A., GANGAPPA, D., SATHYAVATHI, R., MAURYA, R.S. and NARAYANA RAO, D., 2016. Biocompatible silver nanoparticles reduced from Anethum graveolens leaf extract augments the antileishmanial efficacy of miltefosine. Experimental Parasitology, vol. 170, pp. 184-192. http://dx.doi.org/10.1016/j. exppara.2016.09.002. PMid:27622989.

KATIKI, L.M., BARBIERI, A.M.E., ARAUJO, R.C., VERÍSSIMO, C.J., LOUVANDINI, H. and FERREIRA, J.F.S., 2017. Synergistic interaction of ten essential oils against Haemonchus contortus in vitro. Veterinary Parasitology, vol. 243, pp. 47-51. http://dx.doi. org/10.1016/j.vetpar.2017.06.008. PMid:28807309.

KATIKI, L.M., CHAGAS, A.C.S., BIZZO, H.R., FERREIRA, J.F.S. and AMARANTE, A.F.T.D., 2011. Anthelmintic activity of Cymbopogon martinii, Cymbopogon schoenanthus and Mentha piperita essential oils evaluated in four different in vitro tests. Veterinary Parasitology, vol. 183, no. 1-2, pp. 103-108. http:// dx.doi.org/10.1016/j.vetpar.2011.07.001. PMid:21820807.

KAUR, G.J. and ARORA, D.S., 2009. Antibacterial and phytochemical screening of Anethum graveolens, Foeniculum vulgare and Trachyspermum ammi. BMC Complementary and Alternative Medicine, vol. 9, no. 1, pp. 30. http://dx.doi. org/10.1186/1472-6882-9-30. PMid:19656417.

KHANI, A. and BASAVAND, F., 2013. Chemical composition and insecticide activity of essential oil from dill seeds. International Journal of Agriculture, vol. 3, no. 3, pp. 489.

KUMARASINGHA, R., PRESTON, S., YEO, T.C., LIM, D.S.L., TU, C.L., PALOMBO, E.A., SHAW, J.M., GASSER, R.B. and BOAG, P.R., 2016. Anthelmintic activity of selected ethno-medicinal plant extracts on parasitic stages of Haemonchus contortus. Parasites \& Vectors, vol. 9, no. 1, pp. 187-193. http:// dx.doi.org/10.1186/s13071-016-1458-9. PMid:27036205.

MA, B., BAN, X., HUANG, B., HE, J., TIAN, J., ZENG, H., CHEN, Y. and WANG, Y., 2015. Interference and mechanism of dill seed essential oil and contribution of carvone and limonene in preventing Sclerotinia rot of rapeseed. PLoS One, vol. 10, no. 7, pp. e0131733. http://dx.doi.org/10.1371/journal.pone.0131733. PMid:26133771

MACEDO, I.T., BEVILAQUA, C.M., OLIVEIRA, L.M., CAMURÇA-VASCONCELOS, A.L., VIEIRA, L.S., OLIVEIRA, F.R., QUEIROZ-JUNIOR, E.M., PORTELA, B.G., BARROS, R.S. and CHAGAS, A.C., 2009. Atividade ovicida e larvicida in vitro do óleo essencial de Eucalyptus globulus sobre Haemonchus contortus. Revista Brasileira de Parasitologia Veterinária, vol. 18, no. 3, pp. 62-66. http://dx.doi.org/10.4322/rbpv.01803011. PMid:19772778

MOSMANN, T., 1983. Rapid colorimetrie assay for cellular growth and survival: application to proliferation and cytotoxicity assays. Journal of Immunological Methods, vol. 65, no. 1-2, pp. 55-63. http://dx.doi.org/10.1016/0022-1759(83)90303-4. PMid:6606682.

ORHAN, I.E., SENOL, F.S., OZTURK, N., CELIK, S.A., PULUR, A. and KAN, Y., 2013. Phytochemical contents and enzyme inhibitory and antioxidant properties of i graveolens L.(dill) samples cultivated under organic and conventional agricultural conditions. Food and Chemical Toxicology, vol. 59, pp. 96-103. http://dx.doi.org/10.1016/j.fct.2013.05.053. PMid:23764360.

PESSOA, L.M., MORAIS, S.M., BEVILAQUA, C.M.L. and LUCIANO, J.H.S., 2002. Anthelmintic activity of essential oil of Ocimum gratissimum Linn. and eugenol against Haemonchus contortus. Veterinary Parasitology, vol. 109, no. 1-2, pp. 59-63. http://dx.doi.org/10.1016/S0304-4017(02)00253-4. PMid:12383625.

PINTO, N.B., CASTRO, L.M., ALMEIDA CAPELLA, G., MOTTA, T.O., DE MOURA, M.Q., BERNE, M.E.A. and LEITE, F.P.L., 2017. Controlling gastrointestinal nematodes in cattle by Bacillus species. Veterinary Parasitology, vol. 245, pp. 1-4. http://dx.doi.org/10.1016/j.vetpar.2017.08.004. PMid:28969826.

RIBEIRO, W.L.C., MACEDO, I.T.F., SANTOS, J.M.L., DE OLIVEIRA, E.F., CAMURÇA-VASCONCELOS, A.L.F., PAULA, H.C.B. and BEVILAQUA, C.M.L., 2013. Activity of chitosanencapsulated Eucalyptus staigeriana essential oil on Haemonchus contortus. Experimental Parasitology, vol. 135, no. 1, pp. 24-29. http://dx.doi.org/10.1016/j.exppara.2013.05.014. PMid:23748159.

ROBERTS, F.H.S. and O’Sullivan, S.P., 1950. Methods for egg counts and larvae cultures for strongyles infesting the gastrointestinal tract of cattle. Australian Journal of Agricultural Research, vol. 1, no. 1, pp. 99-102. http://dx.doi.org/10.1071/AR9500099.

SAHIB, A.S., MOHAMMED, I.H. and SLOO, S.A., 2014. Antigiardial effect of Anethum graveolens aqueous extract in children. Journal of Intercultural Ethnopharmacology, vol. 3, no. 3, pp. 109-112. http://dx.doi.org/10.5455/jice.20140523104104. PMid:26401357.

SINGH, G., MAURYA, S., LAMPASONA, M.P. and CATALAN, C., 2005. Chemical constituents, antimicrobial investigations, and antioxidative potentials of Anethum graveolens L. essential oil and acetone extract: part 52. Journal of Food Science, vol. 70, no. 4, pp. M208-M215. http://dx.doi.org/10.1111/j.1365-2621.2005. tb07190.x.

SINTIM, H.Y., BURKHARDT, A., GAWDE, A., CANTRELL, C.L., ASTATKIE, T., OBOUR, A.E., ZHELJAZKOV, V.D. and SCHLEGEL, V., 2015. Hydrodistillation time affects dill seed essential oil yield, composition, and bioactivity. Industrial Crops and Products, vol. 63, no. 9, pp. 190-196. http://dx.doi. org/10.1016/j.indcrop.2014.09.058.

SŁUPSKI, J., LISIEWSKA, Z. and KMIECIK, W., 2005. Contents of macro and microelements in fresh and frozen dill (Anethum graveolens L.). Food Chemistry, vol. 91, no. 4, pp. 737-743. http://dx.doi.org/10.1016/j.foodchem.2004.06.046.

VIEIRA, J.N., GONÇALVES, C.L., VILLARREAL, J.P.V., GONÇALVES, V.M., LUND, R.G., FREITAG, R.A., SILVA, A.F. and NASCENTE, P.S., 2019. Chemical composition of essential oils from the apiaceae family, cytotoxicity, and their antifungal activity in vitro against Candida species from oral cavity. Brazilian Journal of Biology = Revista Brasileira de Biologia, vol. 79, no. 3, pp. 432-437. http://dx.doi.org/10.1590/1519-6984.182206. PMid:30328892.

YOSHIHARA, E., MINHO, A.P., CARDIM, S.T., TABACOW, V.B.D. and YAMAMURA, M.H., 2014. In vitro ovicidal and larvicidal activity of condensed tannins on gastrointestinal nematode infestations in sheep (Ovis aries). Semina: Ciências Agrárias, vol. 35, no. 6, pp. 3173-3180. http://dx.doi.org/10.5433/1679$0359.2014 \mathrm{v} 35 \mathrm{n} 6 \mathrm{p} 3173$. 